\title{
Honoured guests
}

Indonesian-American cultural traffic, 1953-1957

Tony Day

In March 1956, the head of the United States Information Agency (USIA, known outside the United States as USIS, United States Information Service) reported to the US Congressional Committee on Foreign Affairs that the dancer Martha Graham and her company, recently returned from their 1955-1956 tour of Asia, had taken Jakarta by storm. According to the Jakarta press, Theodore Streibert ${ }^{1}$ boasted, 'Miss Graham has dispelled the prevalent notion that Americans live in a cultural wasteland peopled only with gadgets and frankfurters and atom bombs' (quoted in Prevots 1998:50). An American Embassy summary of Indonesian press reports sent to Washington conveyed the conviction that 'Graham touched the viewers' hearts and minds by subtly interpreting facets of American life: problems of materialistic society, love between persons of different ethnic origin, and the individual's opportunities in a democratic society' (Frey 2003:543).

In this essay I want to examine the nature and formation of prevalent notions about Indonesia in America and of America in Indonesia between 1953 and 1957, the years of the first Eisenhower administration (or the two Ali and the Burhanuddin cabinets). This was an important liminal period in the history of relations between the two countries. I say 'liminal' because until the intensification of efforts by the Indonesian government to defeat the regional rebellions that were receiving overt American support by early 1958, neither country had become a 'dirty word' for the other (Budiawan 2006:652; Baskara T. Wardaya 2007:213-89). Eisenhower initially pursued the policy of non-interference in Indonesian affairs he inherited from his predecessor Truman, shifting toward one involving active attempts to woo Indonesia into the American bloc, before attempting to overthrow Soekarno altogether (Baskara T. Wardaya 2007:151-209). Relations

1 Theodore Streibert headed USIA from 1953 to 1956. For a detailed discussion of his background, policies, and ideas, see Cull 2008:96-133. 
and perceptions between the Third World and the First, as well as those between, and even within, the competing blocs of the Cold War, were also still very much in flux during these years.

1956 in particular was a year of uncertain direction in the evolving relationship between Indonesia and the United States. It was the year in which Khrushchev denounced Stalin; Nasser nationalized the Suez Canal; anti-Soviet uprisings occurred in Poland and Hungary; and Fidel Castro and his followers started their revolution in Cuba. Coming after the Bandung Afro-Asian Conference and the holding of Indonesia's first democratic elections in 1955 and before the political events of 1957 that led to regional rebellions backed by the CIA in an attempt to destroy Soekarno and the Communist Party, the year 1956 also witnessed a major effort by the United States to 'bring President Sukarno over to our side [...] [or] at least neutralize his tremendous influence', as US Vice-President Richard Nixon put it in May 1955 (Baskara T. Wardaya 2007:179). The middle years of the 1950s in Indonesia (see Foulcher in this volume) and the United States (as we shall see) were also ones of curiosity and cultural traffic, of openness to other cultures, the pressures of the ever-sharpening differences generated by the Cold War notwithstanding.

\section{'SOEKARNO' AND 'AMERICA' IN THE EYES OF THE OTHER}

It had been the job of the USIA, a government agency established in 1953 and reporting through the National Security Council to President Eisenhower, to publicize and coordinate Graham's four performances and a lecture-demonstration in Indonesia in early December $1955 .{ }^{2}$ With the fall of Dien Bien Phu to Vietnamese communist forces in May 1954 and heightened American fears that yet more Southeast Asian 'dominos' would fall, Graham's tour of Japan, the Philippines, Thailand, Malaya, Indonesia, Burma, Ceylon, India, and Pakistan enacted an increasingly urgent American attempt to 'contain' the spread of communism in Asia through cultural means (Prevots 1998:44-50). Graham's trip was funded from the 'Emergency Fund for International Affairs', which Eisenhower had requested on 27 July 1954 in order, as he put it, to 'demonstrate the dedication of the United States to peace and human well-being [and] to offset worldwide Communist propaganda

2 According to the notice appearing in the 'Berita Kebudayaan' section of the cultural magazine Budaya (5-1 (January),1956:40), Graham's troupe performed the dances Ardent song, Cave of the heart, and Appalachian spring on the nights of 8, 9, and 10 December in the Gedung Kesenian, Jakarta. Graham also gave a lecture-demonstration on 6 December. She left Indonesia with her 15 dancers on 12 December. 
charges that the United States has no culture [....]' (quoted in Prevots 1998: 11). The Director of USIA Streibert had already dispatched a memorandum to all USIS posts around the world on 6 July asserting that, as a result of his recent trip to Asia, he had become convinced that 'the fundamental importance and lasting quality of cultural relations' necessitated the pursuit of a cultural outreach program by the USIA that would actively present "the culture of the people of the United States - not the culture of an elite or an intelligentsia' to the world in order to counter the Soviet threat (Foreign relations 1984:1773-5).

In the 1950s the USIA had 10,000 employees, mostly locals, in 217 posts in 76 countries around the world; by 1960, Southeast Asia alone had 58 USIS offices (Frey 2003:550-51). USIA operated the radio program Voice of America (VOA), which started broadcasting in Indonesian and Vietnamese in 1949. During the 1950s, the VOA Indonesian program played to between 500,000 (1955) to 794,700 (1958) radio sets for two hours a day. ${ }^{3}$ USIA also published books and pamphlets, ran libraries, made and showed films, conducted 'exchangeof-persons' programs, and cooperated with the CIA in 'all kinds of propaganda and psychological warfare programs' (Frey 2003:550-2.). Showing films to rural populations was considered especially important. USIA produced and showed its own documentaries by means of 'mobile film units' ('small trucks equipped with film projectors, diesel generators, and screens' introduced into Indonesia in late 1950), but it also helped market Hollywood movies. ${ }^{4}$ Marc Frey (2003:554) comments: 'USIA statistics from all the countries of Southeast Asia are indeed staggering. American officials stationed in Jakarta estimated that around 10 million Indonesians had seen a USIS film during 1953'.

Since late 1954, US policy makers in the Eisenhower administration had been of one mind about their intention to actively intervene in Indonesia in order to prevent the country from falling into the hands of communists, however wildly divergent the means that would

3 Goralski 1960:89-96. Robert Goralski (1960:95-6) gives the typical VOA Indonesian weekly program as follows: 'Sunday: "Listener's choice" (music request program); "Cultural column" (feature material on U.S. cultural developments); "Footnotes to the news" (background data on current affairs). Monday: "Announcer's choice" (music program); "Report from Indonesia" (alternates with "Report on the U.N." and "news of Hawaii"); "Press opinion" (review of U.S. press comment). Tuesday: "Magazine of the air" (feature or documentary program); "American history". Wednesday: "On the scene reporter" (documentary visits to U.S. cities); "Economic digest". Thursday: "Guest of the week" (interview with Indonesian visitor to U.S.); "Labor news". Friday: "Answers to listeners' questions"; "Developments in the world of science". Saturday: "Saturday night showcase" (popular music); "America this week" (documentary covering major news events in the U.S.)'.

4 Frey 2003:553. Nicholas Cull (2008:109) observes that by 1954, 'more than two-thirds of USIA's anti-Communist films were made in the field, with local settings and local talent'. USIS made more films in Southeast Asia than anywhere else in the world (Cull 2008:109). For more on Hollywood's role in marketing USIA films abroad, see Cull 2008:110-1. 
be contemplated or employed by various officials and agencies (Baskara T. Wardaya 2007:168). Even as National Security Council staff worked during January 1955 to plan a propaganda strategy to counter expected communist influence at the upcoming Afro-Asian conference to be held in Bandung in April, the CIA was hatching a plot to disrupt the conference by assassinating Soekarno himself (Baskara T. Wardaya 2007:169-71). In Jakarta, the American Ambassador Hugh S. Cumming, Jr. (1953-1957) used exaggerated US press reports about a warming of relations between the US and Indonesia in early 1955 to nudge Soekarno away from what the Americans perceived as the growing influence of the PKI. Cumming reported to Washington that during their thirty-minute conversation on 24 February, for example, he and Soekarno spent half the time talking about Balinese painting, before moving on to the highly contentious issue of Irian, which the Americans sought to defuse by announcing, only the day before, a US \$ 7 million technical assistance grant to Indonesia (Foreign relations 1989:138-9). The resignation of the PNI-dominated cabinet under former Ambassador to the United States Ali Sastroamidjojo on 24 July 1955 and the formation of a new, Masjumi-led cabinet hostile to the policies and corruption of the preceding government encouraged American officials to hope for more leverage in the struggle against the rise of communism in Indonesia (Foreign relations 1989:194-5; Feith 1962:331-461). But the results of the first-ever Indonesian parliamentary elections in September were disappointing: the (to American eyes) communist-friendly PNI, and not as the Americans had hoped, the Islamic and staunchly anti-communist Masjumi, made the stronger showing. The one clear policy conclusion to be drawn, as Ambassador Cumming put it in a telegram to the Department of State on 5 December, was that the 'elections appear to have re-confirmed Sukarno as the single most powerful and influential Indonesian political personality and have re-established in good part but not completely his position which had been steadily weakening since late 1953 [...] I believe time has come again to consider inviting him to United States particularly as he is only major non-communist SEA leader who has not been to United States' (Foreign relations 1989:210).

Soekarno arrived in Washington aboard Eisenhower's personal plane on 16 May 1956, accompanied by his son Moh. Guntur and number of high Indonesian officials. ${ }^{5}$

5 For a complete account of Soekarno's trip to the United States, Canada, Italy, West Germany, and Switzerland, 4 May-3 July, 1956, see Winoto Danoeasmoro 1956. Winoto Danoeasmoro includes quotes from newspaper notices before, during, and after the trip, texts of all Soekarno's speeches in the languages in which they were delivered, as well as many photographs. My thanks to Jennifer Lindsay for bringing Winoto Danoeasmoro's book to my attention. 


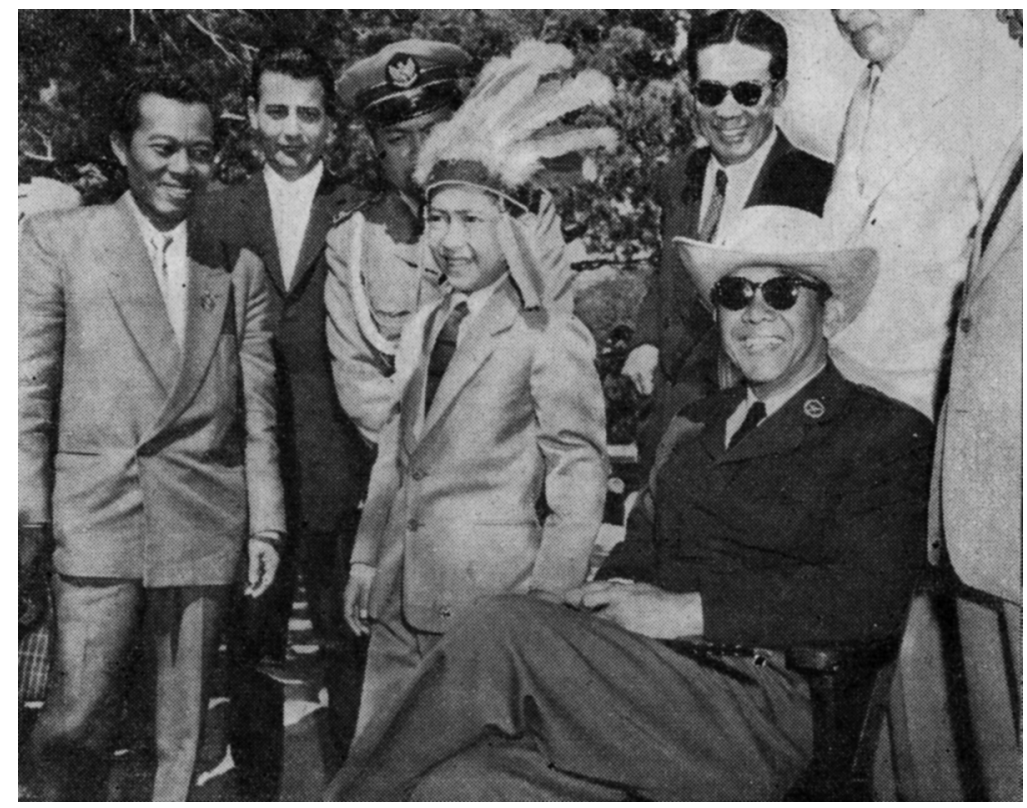

Soekarno in a cowboy hat, with his son Guntur as an Indian chief, during their visit to the Grand Canyon on 29 May 1956. (Winoto Danoeasmoro 1956:109)

On the following day, Soekarno addressed both houses of Congress. After introducing himself in flawless English as 'a man born in a cottage and grown up among poor people', Soekarno went on to say:

In our contemporary world, the impact of America is felt more and more. The influence of the American with his outlook, his ideas, his technical and scientific advances, reaches to almost every corner of Asia and Africa, whilst in America itself, Asia, the Asian and his personality, his ideals, the fruits of his labor, are gradually becoming a living reality. Americans and Indonesians are no longer strangers to each other. We know each other from the films; the beams of the radio reach into our very homes; and the magazines and daily press provoke us to think of each other. These cultural exchanges, coupled with the products of your industries and the fruits of our soil, have kept us always much closer together than the thousands of sea miles which separate our two countries. (DSB 1956:928.) 
It is important to note Soekarno's emphasis on (what he imagined or hoped to be) the reciprocal nature of the growing cultural intimacy between Indonesians and Americans, an intimacy that USIS had already been encouraging by means of its exchange-ofpersons programs, its film showings, its marketing of Hollywood movies, and its reading rooms, where visitors of all kinds, from Jakarta parliamentarians to hundreds of schoolteachers, could find American law books or student textbooks as their needs required (Frey 2003:563). In his speech, undaunted by America's overshadowing cultural might, Soekarno extolled nationalism, which he asked his audience to recognize, not as some 'out-of-date political doctrine', but as that same 'love of country and the determination to improve it' that had inspired the founders of America (DSB 1956:929). After a brief overview of Indonesia's struggle against colonialism, which was still continuing in the fight to regain West Irian from the Dutch, Soekarno examined Indonesia's progress in advancing the principles of democracy, an ongoing process of translating ideals into practice: 'The development of Indonesia in particular and of certain other countries of Asia in general will be the test case of the success or failure of the modern world's application of democratic principles' (DSB 1956:932). As for technical assistance, for which he expressed his gratitude, Soekarno stated boldly: 'We reject the idea of exchanging intellectual and spiritual independence of physical liberty for momentary advantage' (DSB 1956:933). In his speech to the National Press club on May 18 , Soekarno tried to be even more explicit about the need for Americans to recognize that Asian and African anticolonialism and nationalism were not directed against the West (DSB 1956:937). He even attempted to persuade his listeners that he could discern the true goal of America's anticommunism:

Let us look at the very basic facts of the policy of this country. What is the real object of it? The object is not the defeat of communism in the world. In your view that is a most desirable thing. But it is not the object of your policy. No, I think you would agree, and the leaders of your Nation would agree, that you are seeking a larger freedom for mankind. Communism appears to you to stand in the way of that object: therefore you oppose communism. To see the defeat of communism as the end of policy is to confuse military victory with the aims of war. (DSB 1956:937.)

Soekarno's speaking appearances in Washington during his three-day state visit were a huge success. In the words of the Assis- 
tant Secretary of State, Walter Robertson, 'George Washington himself couldn't have made a speech that sounded better to this Congress [...]' (Baskara T. Wardaya 2007:183). Soekarno's triumphant appearance before Congress was followed by a ticker-tape parade in New York City, visits to Independence Hall in Philadelphia and Abraham Lincoln's birthplace in Springfield, Illinois, an honorary degree at the University of Michigan, and tours of automobile factories, Grand Canyon, Disneyland, and Hollywood. ${ }^{6}$

A National Security Council document from June that year reports that the USIA 'took advantage of Sukarno's popularity and enhanced U.S. prestige' to arrange for the 'widest possible dissemination' of information about the American way of life throughout Indonesia (quoted in Hixson 1998:127). In a telegram to the State Department dated 30 June 1956, Ambassador Cumming reported that 'Sukarno's preconceived ideas on materialism US culture and militaristic overtones underwent substantial revision as result of visit'.

Second plus value acquired was publicity which local press gave President and incidentally US by extensive coverage his trip. As reported in almost daily telegrams, presidential US reception and activities dominated all papers for more than three weeks and heavy (coverage) still continuing although now confined mostly to pictures. USIS whose output accounted for vast bulk of coverage also uncovered some new techniques which hitherto have not been available. Further benefit can be expected from exhibition of trip movies which will be running for probably next year here giving tremendous audience first hand view of US in more accurate version than is usually given movie-goers this country. (Foreign relations 1989:282-3.)

As things turned out, neither Soekarno nor Indonesia's commitment to a neutralist politik bebas-aktif was very much affected in the ways American officials hoped by the Indonesian president's trip to America. America's modest foreign aid overtures in the coming months were overshadowed by the robust offer of a US \$100 million in credit for the purchase of military weapons from Khrushchev (Westad 2007:129). And Soekarno began conceiving a konsepsi for a very un-American kind of 'guided democracy' in Indonesia. He later told Cindy Adams what he remembered from the May trip:

6 See Winoto Danoeasmoro 1956:110-30 for the details of Soekarno's visit to Hollywood, including several photographs of Guntur with Roy Rodgers and the Indonesian text of a speech Soekarno delivered at a Hollywood dinner hosted by Eric Johnston, about whom more below. 
'I very much like Hollywood', he told her, recalling in particular meeting Jayne Mansfield 'wearing a tight velvet sheath with very, very obviously nothing on underneath'. ${ }^{7}$ Secretary of State John Foster Dulles and President Dwight Eisenhower? Not anywhere near so appealing: 'Later I conferred with President Eisenhower and we had an immediate nonmeeting of the minds. At the White House [where Soekarno was kept waiting in the hallway, to his fury] he could manage only to discuss our mutual love for motion pictures' (Sukarno 1965:277).

\section{'INDONESIA' ACCORDING TO READER'S DIGEST}

The concept most commonly associated with American foreign policy during the Cold War is 'containment'. But as early as 1949, well before Eisenhower's cultural outreach initiatives, American policy makers were asking the question: 'We are against communism, but what are we for'? America's mission was not simply to defeat communism: it needed to unite the world behind its goal of spreading democracy and freedom abroad (Klein 2003:38). Drawing on official pronouncements by President Eisenhower and Secretary of State John Foster Dulles between 1953 and 1957, Christina Klein explains the ideological 'imaginary' of US foreign policy:

Where the global imaginary of containment drew on the residual internationalism of the right, with its vision of bulwarks between nations and a mortal conflict between communism and capitalism, the global imaginary of integration drew on the residual internationalism of the left, which imagined the world in terms of open doors that superseded barriers and created pathways between nations [...] In the political rhetoric of integration, relationships of 'cooperation' replaced those of conflict, 'mutuality' replaced enmity, and 'collective security', 'common bonds', and 'community' became the preferred terms for representing the relationship between the United States and the noncommunist world. (Klein 2003:41.)

The fact that American foreign policy makers sought to achieve both containment and integration, drawing on concepts from both

7 Sukarno 1965:276. Actually, it was Marilyn Monroe (at a Beverly Hills party, 1956), but Soekarno was not focusing on her face at the time. See the famous photo at: http://soekarnojakarta. blogspot.com/2007/08/sukarno-and-marilyn-monroe.html. 
the right and the left in America's own political tradition, helps explain the sponsorship by the CIA-funded Congress for Cultural Freedom of the African-American writer Richard Wright to attend the Bandung Conference in April 1955 and to meet with members of the Konfrontasi study group later that May (see Foulcher in this volume). As an ex-communist who had contributed his story of recantation to the most famous anti-communist book in world-wide circulation, The god that failed (Crossman 1949), ${ }^{8}$ Wright's presence in Bandung, along with that of the civil rights leader and Black congressman Adam Clayton Powell Jr., demonstrated the antiracist and hence anticolonial, global-integrationist bona fides of the United States, as well as its committed anticommunism. From an Indonesian perspective, at least that of the Konfrontasi study group, Wright's commitment to social change still sounded too leftist, even though he had ended his essay in The god that failed with the stirring, seemingly universalizing pledge 'to keep alive in our hearts a sense of the inexpressibly human' (Crossman 1949:162). Like Soekarno's doomed attempt to communicate the principles of Asian nationalism and neutralism to American audiences during his trip, Wright apparently failed to explain what the American kind of internationalizing humanism meant to the ex-communist, Black American writer in the 1950 s or why it was applicable to the Indonesian postcolonial situation in the late 1950s.

The American popular monthly Reader's Digest helps us investigate some of the underlying assumptions of American cultural imperialism in Indonesia during the 1950s. Started in 1922 by the son of a Presbyterian preacher, DeWitt Wallace, Reader's Digest was the best-known right-wing, 'middlebrow', monthly print digest of literature, commentary on world affairs, and Americana around the world, including (is my growing sense) Indonesia, reaching a world-wide circulation of 15.5 million monthly readers in 1951 and 100 million by 1967, 'more than any other publication except the Bible' (Klein 2003:69). Containing stories about Asia from its very

8 For more on Arthur Koestler, Richard Crossman, The god that failed, and the role of the CIA in the cultural politics of the Cold War, see Saunders 2000. An Indonesian version of The god that failed appeared in 1955, translated by 'L.E. Hakim', aka El Hakim, aka Abu Hanifah, Usmar Ismail's older brother and a prominent Muslim intellectual and member of Masjumi (see Koestler et al. 1955). My thanks to Ajip Rosidi for identifying the translator for me. In his 1949 play Taufan diatas Asia (Typhoon over Asia), El Hakim argued for a modern Islamic Indonesian nationalism that involved catching up with the scientific West 'as soon as possible. But otherwise we have to throw off all Western fetters. Especially so in religion' (quoted in Teeuw 1994:112). This 'combination of religious and nationalist ideals' (Teeuw 1994:113) in the themes of El Hakim's plays is also a quality found in the thinking and films of Usmar Ismail, an ideological orientation that was by definition neither 'rightist' or 'leftist', according to Choirotun Chisaan 2008:181. 
first issue, Reader's Digest promoted American anti-communist internationalism in ways that served American foreign policy objectives. Although it was never directly funded by the US government (Klein 2003:69), Reader's Digest was undoubtedly a standard item in USIS reading rooms in Indonesia and around the world. After 1950, the magazine focused particularly on Southeast Asia as a region vulnerable to communism. The August and September 1955 issues featured two articles on Indonesia by America's most famous travel writer and journalistic expert on Asia, James A. Michener (19071997), whose 1947 Pulitzer Prize-winning Tales of the South Pacific was the source for Rodgers and Hammerstein's hit musical South Pacific (Michener 1955a, 1955b; for more on Michener's career and writings, see Klein 2003:100-42).

'It is high noon in the spacious tropical city of Bandung, in Indonesia', Michener begins his eyewitness account of the Bandung conference. 'A blazing sun beats down upon the mountains that rim the city, and golden light plays over the wisps of smoke that rise from an active volcano to the north' (Michener 1955a:75). Michener opens his essay as if he were promoting American tourism to Indonesia. Indeed, since 1954, the US State Department had been advocating American travel abroad as a means 'to produce a specifically sentimental tourist who would forge bonds with people around the world by engaging in meaningful exchanges, while at the same time avoiding displays of wealth, power, or racism that could render America's power visible in unattractive ways' (Klein 2003:109).

Suddenly the conference-room burst open and more than 300 reporters press forward with hurried questions. Flash bulbs explode [...] In the streets the waiting crowd begins to shout and Indonesians press forward to see the great starts of this extraordinary show. Nasser of Egypt, more handsome than a movie idol, more rugged than a football star, draws a tremendous ovation. He is obviously the city's darling and the popular hero of the conference. Now comes a deeper, more emotional roar. It is for Nehru of India, the respected leader of millions in Asia who feel that his ideas constitute the only path to peace. (Michener 1955a:75.)

Michener turns the scene in which the conference delegates emerge from their meeting into a Hollywood Oscars night in order to achieve the central ideological objective of the editors of Reader's Digest: 'an international sense of "we"' in which there was no essential difference between Bandung, Hollywood, the reader, Asian leaders, Indonesian onlookers, or Michener himself (Klein 
2003:85). Michener's narrative makes it possible for his American readers to identify with Asians in a way that reassures them that cultural difference "was not something to be feared but accommodated and even celebrated' (Klein 2003:79). This was a form of internationalism that served the central US foreign policy goal of communism-containing global integration.

I do not know if Indonesians who read the Reader's Digest, like the writer and film critic D. Suradji, who cited the magazine in a long piece he wrote on the British film producer Arthur Rank, felt a reciprocal bonding with Americans (Suradji 1961:112). There is in any case nothing equivalent to the American blend of cultural cringe and neo-imperialism that infused and activated cultural categories, or the nationalistic over-confidence that inflated them, in Indonesian ideas about culture, or cultural exchange with other countries that formed an important component of Indonesia's outreach during the early 1950s (Day 2010:136-46; Jones 2005:111-2). As we learn from the essays by Keith Foulcher, Jennifer Lindsay, and Hairus Salim, among others, in this volume, Indonesians were fiercely independent and culturally self-assured, yet still tentative about their newly achieved national identity in the modern, postwar, international world. 'Indonesia' was still very much a work in progress, and it seems doubtful that Indonesians of the early 1950s had as clear a sense of their position and role in the world, either individually or collectively, as American readers of Reader's Digest. On 25 March, 1957, Soedjatmoko, managing director of the Pembangunan publishing house and bookstores and an editor of Pedoman and Siasat, ran a contest to see who would submit the best essay on the following questions published in Suluh Indonesia, Abadi, Harian Rakjat, Pedoman, and six regional papers in Java, Sumatra, and Sulawesi: 'What are we as a nation and a country? What is our goal and our mission in this world, taking into account our specific characteristics, our history, the culture of our people, and also our vision of the future?' (Pauker 1958:306). There were 355 responses from all over Indonesia. In the announcement published on 1 January 1958 in Siasat that there were no first, second, or even third prizewinners. Pauker (1958:308) records that Soedjatmoko commented:

The jury had the impression that in these hundreds of entries the clarity of thinking was frequently subdued by a vivid tendency toward agitation and by the use of stereotypes, while the clarity of exposition suffered from lack of skill in the use of the language. Also, the literary value is still heavily influenced by outmoded literary forms such as the pantun which are obstacles to the free expression of ideas. 
When it came to commenting on Indonesia's position in the world, according to Guy Pauker (1958:311), who helped Soedjatmoko organize the contest along with the Cornell dance scholar Claire Holt (Foulcher in this volume refers to Holt's meeting with the Konfrontasi study group), $10 \%$ of the responses had negative things to say about 'Western' influences on Indonesia, while another $10 \%$ had good things to say about America, the Soviet Union, China, Eastern Europe, Egypt, and Syria. Only 22 entries endorsed Indonesia's official 'independent and active foreign policy', but none recommended specific alliances (Pauker 1958:311). 'By far the most frequent expressions', Pauker observes,

reflect the wish to see Indonesia play an important role in world affairs. What seems characteristic is neither sharp antagonism to foreign nations nor a widespread desire to create permanent ties with other nations, but the desire to see Indonesia play the role of example, teacher, arbiter or conciliator to the world - the longing for national glory. Almost one-fifth of all the entries express this attitude in one form or another (Pauker 1958:308).

James Michener (1955a:76), on the other hand, spends much of the rest of his article articulating a very clear sense of America's global positionality, discussing the 'containment' of the Chinese delegate Chou En-lai in Bandung, who 'was quickly forced to change his line' by staunchly pro-American delegates from Turkey, Pakistan, Thailand, Iran 'and, particularly, the Philippines'. Michener warns his readers that it would be foolish to ignore the delegates' call for the banning of atomic weapons (which would only embolden the Russians to occupy all of Europe) or their condemnation of racism. 'In the bars of Bandung, in the corridors and along the streets an American discovered with dismay that thousands of Asians honestly believe that their major enemy in the world is the United States' (Michener 1955a:78). But Michener finds no evidence in Bandung that Asia is falling into the hands of the communists. On the contrary, Americans, without a past of imperialism and colonialism to feel guilty or defensive about, should be able to feel a deep commonality with 'the biggest outcome [which was] the death of an inferiority complex'; 'Nation after nation found its voice, and in using it freely discovered that it wasn't really so mad at the white man after all' (Michener 1955a:79).

In his more general survey of Indonesia, 'Islands of beauty and turmoil', in the September 1955 issue of Reader's Digest, Michener sounds an initially ominous note in the opening third paragraph: 
'Today Communism from Red China is attempting to establish beachheads on these islands, so that free Indonesia assumes vital importance to the world' (Michener 1955b:30). Michener proceeds to lead the Reader's Digest tourist around the archipelago, from Java, to Bali, the 'Spice Islands', to Sumatra, which Michener found to be 'the most exciting part of Indonesia', with its 'tin, oil, rubber and wealth unknown' as well as its 'high plateaus' that 'comprise the intellectual center of Indonesia, where pleasant towns exist that are mysteriously 100 percent literate' (Michener 1955b:33-4). He then explains Indonesians' apparent indifference to the threat of communism, as opposed to their greater fear of domination by Europe and America, in terms of the failure of Dutch colonialism to foster Indonesian modernization during more than 300 years of Dutch rule. Threatened by corruption and regional separatism, yet endowed with youthful vigour, tolerance, nationalism, and natural wealth, Indonesia, Michener (1955b:37) is convinced, has a future that is secure, 'even against the pressures of Communism'. Even when he is talking about communist 'beachheads' or the 'vital importance' of a 'free Indonesia', Michener (1955b:31) makes Indonesia sound like a place where Americans could feel at home: at the exotic Javanese ritual even known as the 'selamatan', 'in recent years another attraction has surpassed even the food: if a man can afford it, he will erect a movie screen and run off six fulllength features for his guest'.

'HOLLYWOOD’ ACCORDING TO USMAR ISMAIL

The fact that both Soekarno and James Michener associated America with Hollywood in an almost unthinking, reflexive way points to the importance of American films in the shaping of cultural perceptions in Indonesia during the 1950s. During the period 1950-1955, up to 700 American films were imported into Indonesia annually (Sen 1994:24). Through its Technical Cooperation Administration, an agency set up by the Department of State in 1950 to provide 'scientific and technical assistance to underdeveloped countries in order to maintain political stability and to further economic and social progress', the US government provided money, equipment, and personnel for the training of Indonesian filmmakers (Sen 1994; Records n.d.). Although vehement opposition to American films in Indonesia did not develop until the 1960s, there were many in the 1950s who found their omnipresence disturbing (Sen 1994:32-4). The veteran writer and cultural observer Armijn Pane, 
for example, expressed his concern in 1953 that American movies were stimulating Indonesian viewers and filmmakers to 'flee the world of reality into that of fantasy' (Armijn Pane 1955:162). In his regular column 'Inilah Indonesia' for Siasat on 10 October 1956, the journalist 'Tjantrik' commented that the American film 'Rock around the Clock' that had been playing at Jakarta's Astoria theatre for the past two months had caused youngsters in the US and Europe to 'become like people possessed by the devil'; 'Thank God that in our country that creepy movie hasn't (yet?) had evil consequences'. ${ }^{9}$ And yet, up and coming Indonesian filmmakers like Usmar Ismail (1921-1971), who spent a year studying film at the University of California Los Angeles in 1952-1953 funded by the Rockefeller Foundation as a member of the most targeted group of Southeast Asians to participate in USIA-sponsored exchange-ofpersons programs designed to foster "mental and ideological dispositions favorable to the "West" in general and the United States in particular', seized opportunities to learn more about American cinematography. ${ }^{10}$ Elsewhere in this volume, Hairus Salim examines Usmar's visit to Egypt in 1959, his involvement in the founding of the Muslim cultural organization LESBUMI in 1962, and the polarizing political forces of the late 1950s and early 1960s that stimulated his interest in making films with Islamic themes. My own discussion centres on two essays that Usmar published in the newspaper Pedoman in 1953 that shed light on the process of cultural exchange between America and Indonesia in the mid 1950s. ${ }^{11}$

In the first of these essays, 'Lahirnja "Kafedo"' (Usmar Ismail 1983a), published in April 1953, Usmar describes the making of his first film after returning from Los Angeles. The essay is presented as sequence of diary entries. In the first entry, dated 'Ancol 12 Maret 1953', Usmar describes the film as a 'test-case as to whether there is any point for me to go and study in the United States' (Usmar

$9 \quad[\mathrm{~m}]$ endjadi seperti orang-orang jang kesurupan setan; Sjukur alhamdulilah bahwa di negri kita film serem itu tidak (belum?) menimbulkan akibat-akibat jang begitu djahat.

10 Salim Said 1991:55; Sen 1994:38-41; Frey 2003:554. Frey (2003:555) notes that by 1955, 300 Indonesians went to the US annually on grants.

11 In addition to the essays on Hollywood discussed here, Usmar published seven other reports on Hollywood and Hollywood movies in 1952 during his American visit: 'Laporan dari Hollywood: Death of a Salesman', Pikiran Rakjat (Bandung), 4-178 (10 January) 1952; 'Laporan dari Hollywood: Sebuah perumpamaan: Viva Zapata', Mimbar Umum Minggu (Medan) 11-5-1952; 'Oleh-Oleh orang pulang', Aneka 20-9-1952; 'Hollywood yang saya kenal', Duta Suasana 1-24(1 October) 1952; 'Laporan tentang Hollywood', Aneka 22-10-1952; 'Laporan dari Hollywood: A streetcar named desire, Seorang Indonesia melihat sebuah world premiere', oleh pembantu tetap di Hollywood [Usmar Ismail], Mimbar Umum, 18-11-1952; 'Laporan dari Hollywood: Film-Film tentang manusia dari darah dan daging', Mimbar Umum (Medan), 9-12-1952. My thanks to Hairus Salim HS for providing me with this list of Usmar's essays about Hollywood. 
Ismail 1983a:172). Compared to his early years with his film company Perfini, which he established in 1951, things are better organized now; there's new equipment, and a car. But problems start immediately: the electric generator breaks, so he has to use his old camera, which can't record sound (Usmar Ismail 1983a:173). Usmar decides to film a fight scene, without the sound, between Harun, leader of the Laskar Rakyat, and Gawega, a fanatic Kafedo follower, who is accused of siding with the Dutch (but later turns out to be loyal to the Revolution; for a plot synopsis and list of actors, see Kristanto 2005:27). This decision prompts Usmar to reflect on the fact that until now in Indonesia 'the fight scenes have never been good, not like Humphrey Bogart or Kirk Douglas; ${ }^{12}$ his solution is to have the actors train with some Minang martial arts experts (pendekar). To in effect choreograph the fight scene makes it possible to plan it ahead of time as a structured series of discrete 'shots (pengambilan)' (174). In his second diary entry later on in the essay, Usmar returns to some of the technical issues of shooting and editing that make for the qualitative difference between Indonesian and American films (Usmar Ismail 1983a:176). Another idea that Usmar has picked up in Los Angeles is that trained actors are superior to amateur ones. Earlier he had been influenced by the Italian neorealist practice of simply taking a camera into the street and using ordinary people to make films about real life (Salim Said 1991:56). But he was struck when he was in Los Angeles how quickly and intelligently Hollywood stars like Gregory Peck responded to directions (Usmar Ismail 1983a:175). He reflects with amusement on the fact that his critics used to accuse Perfini of being a "junk dealer' (tukang loak); now a critic like Balfas will write in Siasat: 'Usmar is nuts about Hollywood' (Usmar sudah gila Hollywood)! Usmar's ideal is to make high quality films, but as he makes clear in the rest of his essay, the technical and financial obstacles of doing so in Indonesia are daunting. The main point of the essay is to demonstrate Usmar's determination to adapt ideas about making films that he has learned in America to conditions in Indonesia, in order to produce better Indonesian films, however long that takes.

Usmar's second essay, 'Inilah Hollywood' (Usmar Ismail 1983b), can be read as an ironic commentary on the Indonesian film industry and its politics. It's harder to get to see someone like Frank Y. Freeman, Vice President of Paramount Pictures, than it is to make an appointment with Mr. Sumanang, Menteri Perekonomian Republic Indonesia, or Oom Mononutu, Menteri Penerangan RI (Usmar Ismail 1983b:222), Usmar writes, in an ironic reflection on

12 [a]degan perkelahiannya tak pernah baik, tidak seperti Humphrey Bogart atau Kirk Douglas. 
the lowly status on the Indonesian film director. But in a sort of refutation of Michener's sentimental depiction of Americans and their exotic Asian 'others', Usmar implicitly likens the Hollywood mogul to a 1950s Indonesian politician. The heads of the great Hollywood studios are really like 'raja' engaging in constant competition with one another:

\begin{abstract}
Quarreling behind the scenes and in the open, they stab at one other face to face or from behind, insulting each other non-stop, so that to the outsider it seems sometimes that one of them must collapse at a certain point. Each of them has the trait of only looking out for number one and tries constantly to stand in the way of the others. ${ }^{13}$
\end{abstract}

But if Indonesian film producers follow Hollywood's example (which presumably they already do, or why would Usmar make the comment!) and begin a practice of 'clawing at each other', it will be difficult to avoid total disaster (for both the movie industry and the country). Yet in other respects, Hollywood's differences with the Indonesian film world are instructive in a positive sense. Hollywood's elite includes innovative people from humble backgrounds; most of them 'originate from various entertainment businesses, popular theatre, rural movie houses, circuses, and so on'. ${ }^{14}$ These people are equipped with sharp noses for popular taste and cater to the masses; all that matters is 'two letters b.o. (box office), alias profit'. ${ }^{15}$ Their weakness is that they feel inferior to people with intelligence and talent; they give in to 'independent artists' (seniman liar) like Elia Kazan or John Huston (or Usmar Ismail?!) and let them make the films they want, according to their own artistic principles. But this weakness is in fact their strength, for it is artistic creations such as these that make Hollywood the 'center of the world's best filmmaking' (pusat pembikinan film yang terbaik di dunia) (Usmar Ismail 1983b:225). The world of Hollywood may be isolated, a world unto itself, but it is ruled by young people who take risks, are filled with optimism, and who love their work with a passion (Usmar Ismail 1983b:228-9).

13 Perselisihan gelap-gelapan dan terang-terangan saling tikam-menikam dari depan dan dari belakang, jelek-menjelekkan tidak henti-hentinya hingga kadang-kadang bagi orang luaran terasa bahwa salah satunya mesti akan roboh pada suatu waktu. Masing-masing bersikap terlalu mementingkan diri sendiri dan tak putus-putusnya berusaha untuk menghalangi yang lain (Usmar Ismail 1983b:223).

14 [b] erasal dari berbagai-bagai usaha penghibur, ketoprak-ketoprak, bioskop rakyat, komidikomidi kuda dan lainnya (Usmar Ismail 1983b:224).

15 [d] ua huruf b.o. (box office) alias penghasilan (Usmar Ismail 1983b:224). 
Usmar is accomplishing something in both his 1953 Pedoman essays that is unusual for either Indonesian or American observers of transcultural exchange in the 1950s: he sees both the similarities and the differences between his own cultural context and a foreign one that, in only a year of total immersion, he has come to understand pretty well. Usmar was not a cultural tourist, as both Soekarno and James Michener were in different ways. He was an independent-minded Indonesian cinematographer who knew what he needed to learn from America and who took the time and trouble to go there to do so. If there is a longing in his essays for Indonesia to be more like America, at least as far as some aspects of its movie industry is concerned, there is also expression of a strong commitment to making films in Indonesia and to struggling with Indonesian social and economic conditions in order to do so. In depicting the positive aspects of Hollywood filmmaking practices in his essays, Usmar was not unlike Soekarno in his speech to Congress in 1956, reaching out to America's better, non-ideological, pre-Cold War self in a spirit of solidarity with the ideals of independence and universal human freedom.

In this (still very exploratory) essay I have tried to sketch a framework for examining cultural traffic between Indonesia and the United States in the mid-1950s, a liminal period in relations of all kinds between the two countries, when official policies and unofficial attitudes had not yet hardened into Cold War dogmas. The thread that connects Soekarno to James Michener to Usmar Ismail, politicians high and low to Indonesian peasants to USIA to the 'middlebrow' American subscriber to Reader's Digest, is Hollywood. Not only jazz, pop music, and Tarzan comics but also American films flooded Indonesia in the late 1950s. Hollywood movies constituted a powerful popular medium through which American culture and cultural attitudes were communicated to Indonesians at all levels of society, in ways and to a degree that remain to be investigated. Hollywood also provided the exotic, Orientalized scenarios by means of which popular American writers like James Michener created images of 'Indonesia' and its culture with which Americans could conjure forth 'an international sense of "we". 
Existing studies of the film industry in Indonesia pay no attention to the impact of American movies on the Indonesian imagination, even though these studies record the attempts by the fledgling Indonesian film industry and, in the early 1960s, by outraged Indonesian viewers on the left to control the flood of American films into the country (Sen 1994:29-36; Said 1991:69-75). Consumers of American films like Usmar Ismail and Soekarno, however, not only watched a lot of American movies, they thought long and hard about what they were watching. Here, for example, is a comment Soekarno made to Cindy Adams, one that illustrates his disappointment in American incomprehension of Afro-Asian anticolonialism and nationalism:

I asked the late Eric Johnson ${ }^{16}$ Chairman ${ }^{17}$ of the American Motion Pictures Corporation, ${ }^{18}$ about a United Artists film called, 'Broken Arrow,' the story of a great love between an Indian squaw and an American officer. 'Why has this Indian girl to die in the end? Why can't you make them a happy couple? How do you think we feel at such obvious maneuvers on the screen? Your color barrier, which even in the movies shows dark skin as plainly inferior, is a disgust to the Asian!'

Replied Johns[t]on, 'The film business is a business to make money. The [American] South would boycott it if the white man and brown girl ended up living happily in society.'

Films should be instruments to promote world solidarity, not kill it. Here's an inexpensive way to show us kindness. Never mind the dollars. Just make films showing you like us. Yet even in make-believe situations America tears us apart. (Sukarno 1965:298.)

As far as Usmar Ismail's ideas about Hollywood are concerned, there is at least one essay waiting to be written about American influences on the cultural imaginary of his own movies. Usmar's

16 This should be: Johnston.

17 This should be: president.

18 Johnston was the key figure in coordinating relations between Hollywood and the US State Department, which involved the careful vetting of scripts to ensure that Hollywood films conveyed positive impressions of America abroad (Cull 2008:84). Johnston hosted Soekarno in Hollywood in May 1956. According to Siasat's 'Kronik Kebudajaan' in the issue of 21 March 1956, Johnston arrived in Jakarta as a personal envoy from President Eisenhower 'to inspect development projects having to do with US technical assistance” (untuk memeriksa projek-projek pembangunan jang berhubungan dengan bantuan tehnis A.S). 
masterpiece of political satire, Tamu Agung (1955), for example, if compared to the American film that inspired it, Henry Koster's Cold War musical based on a play of the same name by Nikolai Gogol, The Inspector General (1949), starring Danny Kaye in the title role, would demonstrate, I think, that Usmar had a critical, Indonesian nationalist take, not just on the authoritarian politics of Soekarno, who would travel to America the following year as a 'tamu agung', honoured guest, of a US government anxious to secure his allegiance during the Cold War, but also on Hollywood itself, America's most powerful, entrancing, and disturbing cultural 'guest' in Indonesia. ${ }^{19}$

I do not know how much more material as insightful as Soekarno's comments to Cindy Adams or Usmar Ismail's reflections on Hollywood await discovery or to what extent it would reveal the inner workings of the Indonesian postcolonial imagination and its response to American culture in the formative years of the new republic. ${ }^{20}$ At least one piece of critical commentary on Martha Graham's performances that I know of, published in Siasat on 25 January 1956 by Asrul Sani (1997a), another beneficiary of a USIA exchange-of-persons scholarship to the United States and a close associate of Usmar Ismail's, suggests that thoughtful Indonesian viewers had a more sophisticated and nuanced response to avant garde American culture than USIS officials imagined or desired. In the same year Asrul also wrote an interesting and contentious review for Kisah of the first-ever American anthology of Indonesian literature and topical essays in translation, published in 1956 as a supplement to the Atlantic Monthly magazine by a Ford Foundation-funded organization known as Intercultural Publications Inc. (Asrul Sani 1997b; Perspective 1956). The list of contributors to this collection reads like a roll call of Gelanggang, Konfrontasi, and PSI supporters, except for one Pramoedya Ananta Toer. Like the opinions of Hollywood movies surveyed in this essay, and as James Michener, very much to his credit as an observer of newly independent Indonesia, would agree, the Atlantic Monthly anthology of Indonesian writing suggests that, despite the best efforts of the United States and its agencies to bring Indonesia into the American Cold War camp during the mid-1950s, Indonesians preferred their own 'third way'.

19 Asrul Sani published a translation of Gogol's play in 1986 (Gogol 1986). I don't know whether it was available to Usmar Ismail in published or unpublished form in 1955.

20 For instance, Hamka's account (1954) of his four month stay in the US in the early 1950s and H.B. Jassin's letters (1984) during his visit to the US in the early 1960s are examples of sources awaiting further study. 


\section{REFERENCES}

Armijn Pane

1955

'De productie van speelfilms in Indonesië', Cultureel Nieuws Indonesië 1955 41-2:131-65. [First published in Indonesia, Jan-Feb 1953.]

Asrul Sani

1997a

'Surat dari Jakarta (IV)', in: Asrul Sani, Surat-surat kepercayaan, pp. 520-7. Jakarta: Pustaka Jaya.

1997b 'Indonesia bicara buat diri sendiri', in: Asrul Sani, Suratsurat kepercayaan, pp. 648-53. Jakarta: Pustaka Jaya.

Baskara T. Wardaya

2007

Cold War shadow; United States policy toward Indonesia, 19531963. Yogyakarta: Galangpress.

Budiawan

2006

'Seeing the communist past through the lens of a CIA consultant; Guy J. Pauker on the Indonesian Communist Party before and after the "1965 Affair"'. Inter-Asia Cultural Studies 7-4:650-62.

Choirotun Chisaan

2008 Lesbumi; Strategi politik kebudayaan. Yogyakarta: LKIS.

Crossman, Richard (ed.)

1949 The god that failed. New York: Harper and Brothers.

Cull, Nicholas J.

2008 The Cold War and the United States Information Agency; American propaganda and public diplomacy, 1945-1989. Cambridge: CUP.

Day, Tony

2010

Imagining world literature during the Cold War in Indonesia and Vietnam in: Tony Day and Maya H.T. Liem (eds), Cultures at war; The Cold War and cultural expression in Southeast Asia, pp.131-69. Ithaca, NY: Southeast Asia Program (SEAP), Cornell University. [Studies on Southeast Asia 51.]

DSB

1956 Department of State Bulletin. Vol. XXXIV, no. 884. [4 June.]

Feith, Herbert

1962 The decline of constitutional democracy in Indonesia. Ithaca: Cornell University Press. 
Frey, Marc

2003

'Tools of empire; Persuasion and the United States' modernizing mission in Southeast Asia'. Diplomatic History 27-4 (September):543-68.

Foreign relations

1984

Foreign relations of the United States, 1952-54. Vol. II, Part 2: National security affairs. http://digital.library.wisc. edu/1711.dl/FRUS.FRUS195254v02p2.

1989 Foreign relations of the United States, 1955-1957. Vol. XXII: Southeast Asia. http://digital.library.wisc.edu/1711.dl/ FRUS.FRUS195557v22.

Gogol, Nikolai

1986

Inspektur Jenderal. Jakarta: Pustaka Jaya. [Translation by Asrul Sani.]

Goralski, Robert S.

1960 'Radio broadcasting in Asia and the "Voice of America".

Studies on Asia, Series 1, vol. 1, University of Nebraska: 88-97.

Hamka (Hadji Abdul Malik Karim Abdullah)

1954 Empat bilan di Amerika. Djakarta: Tintamas.

Hixson, Walter L.

1998 Parting the curtain; Propaganda, culture, and the Cold War, 1945-1961. New York: St. Martin's Griffin.

Jassin, H.B.

1984 Surat-Surat 1943-1983. Jakarta: Gramedia.

Jones, Tod

2005

Indonesian cultural policy, 1950-2003; Culture, institutions, government. PhD thesis, Curtin University of Technology.

Klein, Christina

2003 Cold War orientalism; Asia in the middlebrow imagination, 1945-

1961. Berkeley/Los Angeles/London: University of California Press.

Koestler, Arthur et al.

1955

Kegagalan 'Tuhan'-Komunis. Titel aseli; the god that failed. Bandung: Front Anti Komunis Indonesia. [Translation L.E. Hakim (pseudonym of Abu/Aboe Hanifah).]

Kristanto, J.B.

2005

Katalog film Indonesia 1926-2005. Jakarta: Penerbit Nalar bekerjasama dengan Fakultas Film dan Televisi, Institut Kesenian Jakarta [and] Sinematek Indonesia. 
Michener, James A.

1955a 'Historic meeting in Indonesia', Reader's Digest, August:75-9.

1955b 'Indonesia; Islands of beauty and turmoil', Reader's Digest, September:30-8.

Pauker, Guy J.

1958

'Indonesian images of their national self', The Public Opinion Quarterly 22-3:305-24.

Perspective

1956 Perspective of Indonesia. New York: Intercultural Publications Inc.

Prevots, Naima

1998 Dance for export; Cultural diplomacy and the Cold War. Hanover and London: Wesleyan University Press.

Records

n.d. Records of U.S. foreign assistance agencies, 1948-1961. http://

Salim Said

1991 Shadows on the silver screen; A social history of Indonesian film. Jakarta: The Lontar Foundation.

Saunders, Frances Stonor

$2000 \quad$ The cultural Cold War; The CIA and the world of arts and letters. New York: The New Press.

Sen, Krishna

1994

Indonesian cinema; Framing the New Order. London/New Jersey: Zed Books.

Sukarno

1965

Sukarno; An autobiography as told to Cindy Adams. Indianapolis: Bobbs-Merrill.

Suradji, D.

1961

'Arthur Rank', in: Bertebaran ditunggalkan; Rangkuman tulisan menjinari seni-drama, film, lukis dan sketsa ibukota R.I.S., pp. 106-13. Djakarta: Haruman Hidup.

Teeuw, A.

1994

Modern Indonesian literature .Vol. 1. Fourth edition. Leiden: KITLV Press.

Usmar Ismail

$1983 a$

'Lahirnya "Kafedo"', in: Usmar Ismail, Usmar Ismail mengupas film, pp. 172-81. Jakarta: Penerbit Sinar Harapan.

1983b 'Inilah Hollywood', in: Usmar Ismail, Usmar Ismail mengupas film, pp. 222-30. Jakarta: Penerbit Sinar Harapan. 
Westad, Odd Arne

2007

The global Cold War; Third World interventions and the making of our times. Cambridge: Cambridge University Press.

Winoto Danoeasmoro

1956 Perjalanan P.J.M. Presiden Ir. Dr. Hadji Achmad Sukarno ke Amerika dan Eropah. Tjet. ke-2. Djakarta: Penerbit Grafica. 